\title{
EFFECTS OF CALCIUM ON THE CORONARY AND SYSTEMIC CIRCULATION IN PATIENTS AFTER CORONARY SURGERY
}

\author{
Emerson A. Moffitt, Dhun H. Sethna, Richard J. Gray, John Bussell, Carolyn M. \\ CONKLiN and JaCk M. Matloff
}

\begin{abstract}
Nine patients were studied three hours after aorto-coronary bypass. Before anaesthesia a radial arterial cannula was inserted and a thermodilution catheter placed into the pulmonary artery by fluoroscopy. A special thermodilution catheter was manipulated into the coronary sinus. Haemodynamic measurements were made plus cardiac output and coronary sinus blood flow. Content of oxygen and lactate in arterial and coronary sinus blood was determined. Series of measurements were done before and after $1 \mathrm{gm} \mathrm{of} \mathrm{CaCl}_{2}$ given intravenously over 15 minutes. Calcium increased cardiac index and arterial pressure but not systemic vascular resistance. Total coronary sinus blood flow did not change, nor did myocardial oxygen consumption or coronary sinus oxygen content. Content of lactate in arterial and coronary sinus blood was unaltered and lactate extraction by the heart continued, in eight of nine patients. The improved haemodynamics were accomplished without inordinate risk to global ventricular energy metabolism.
\end{abstract}

KEY WORDS: HEART, blood flow, coronary artery; myocardial oxygen consumption; effect of calcium: VASCULAR RESISTANCE, systemic, effect of calcium; SURGERY, coronary artery bypass graft.

Calcium CHLORIDE $\left(\mathrm{CaCl}_{2}\right)$ is frequently given during anaesthesia for cardiac operations and in cardiopulmonary resuscitation to increase myocardial performance, thus improving cardiac output and blood pressure. A basic unanswered question is: In improving cardiac performance, is myocardial oxygen consumption $\left(\mathrm{MVO}_{2}\right)$ increased beyond oxygen supply? If effective in producing a better circulation, is $\mathrm{CaCl}_{2}$ good or bad for myocardial energy metabolism?

Previous studies of $\mathrm{CaCl}_{2}$ have focused on its effects on cardiac output and vascular resistance but none have examined myocardial energy metabolism. Denlinger and co-workers reported that $7 \mathrm{mg} \cdot \mathrm{kg}^{-1}$, during halothane anaesthesia in healthy men, increased cardiac index and lowered systemic vascular resistance (SVR) and heart rate.' Conversely, Lappas, et al. ${ }^{2}$ found that a

Emerson A. Moffitt, M.D., Professor of Anaesthesia, Dalhousie University; Dhun $\mathbf{H}$. Sethna, M.D.; Richard J. Gray, M.D.; Jack M. Matloff, M.D. and Carolyn M. Conklin, R.N., Department of Cardiothoracic Surgery; John A. Bussell, Department of Anesthesiology, CedarsSinai Medical Centre, Los Angeles, California.

Address for reprints: E.A. Moffitt, M.D., Sir Charles Tupper Medical Building, University, Avenue, Halifax, Nova Scotia, B3H $4 \mathrm{H} 7$.

Can. Anaesth. Soc. J., vol. 29, no. 4, July 1982
$5 \mathrm{mg} \cdot \mathrm{kg}^{-1}$ bolus produced an elevated $S \cdot R$ and arterial pressure in patients having coronary artery bypass grafting (CABG), with little change in cardiac output.

Because of its regular use and effectiveness in cardiac anaesthesia and the question of its safety relative to myocardial oxygen balance, we studied $\mathrm{CaCl}_{2}$ in nine patients. Three hours after $\mathrm{CABG}$ we measured cardiac and haemodynamic effects, including coronary blood flow and lactate extraction by the left ventricle.

\section{Investigative Procedure}

This study was part of a larger one of thirty patient ${ }^{3}$ which encompassed the period from before induction of anaesthesia, through operation and whole body perfusion for CABG and for 24 hours afterward. The protocol was approved by the Human Subjects Committee of CedarsSinai Medical Centre and informed consent was obtained.

\section{Patients Studied}

The nine patients had significant coronary arterial disease (Table I) but with adequate myocardial function still present. Five patients 
TABLE I

Patients Studied

Patients: $9 ; 5$ female, 4 male

Age: $\mathrm{m}=60.3$ years

Weight: $m=68.2 \mathrm{~kg}$

New York Heart Association: Class II -4

$$
\text { Class III }-3
$$

Class IV - 2

Ejection fraction: $m=0.77$

On propranolol -7

Previous myocardial infarction ?

No. of vein grafts $=3.3$ /patient

had been anaesthetized with morphine-oxygen $\left(1 \mathrm{mg} \cdot \mathrm{kg}^{-1}\right)$ and four received halothaneoxygen. The mean duration of anaesthesia was 298 minutes; mean pump time was 123 minutes and mean period of aortic clamping was 72 minutes. All patients were judged by the surgeon to be completely revascularized since all vessels with greater than 50 per cent obstruction were bypassed. None of the patients had perioperative infarction.

\section{METHODS}

Before induction of anaesthesia in the operating room, under premedication (secobarbitone, mean $225 \mathrm{mg}$ ) and local anaesthesia (lidocaine) a radial artery cannula was placed and two thermodilution catheters were inserted through the right internal jugular vein. One was the usual pulmonary arterial catheter ${ }^{4}$ (Edwards Co.) and the other was manipulated into the mid-coronary sinus by fluroscopy. This special catheters (Wilton-Webster Laboratories) measures total coronary sinus blood flow, which essentially equals left coronary arterial flow. Each series of the study consisted of determining coronary blood flow, cardiac output, arterial and central cardiac pressures, plus taking arterial and coronary sinus samples for oxygen and lactate content. Lactate determinations were done in duplicate by a modification of the Marbach method. ${ }^{6}$ Haemoglobin and oxygen saturation were measured by co-oximetry (IL Ca-oximeter, Model 282).

Haemodynamic indices were calculated from standard formulae. ${ }^{7}$ Metabolic indices were calculated. The ratio for lactate extraction by the myocardium = ART-CS/ART, where ART and $\mathrm{CS}$ are the arterial and coronary sinus concentrations of lactate $(\mathrm{mmol} / \mathrm{l}) . \mathrm{MVO}_{2}(\mathrm{ml} / \mathrm{min})=$ CSBF (ml/min) $\times$ ART-CS oxygen content $(\mathrm{ml} / 100 \mathrm{ml})$. Friedman's two-way analysis of variance and the Wilcoxon paired rank test were the statistical analyses.

After three hours in the Intensive Care Unit a control series of measurements was done. At this time mean body temperature was $35.3^{\circ} \mathrm{C}$; the patients were still drowsy and were being ventilated with 50 per cent oxygen. No other cardioactive drugs had been given since the end of operation. Then $\mathrm{CaCl}_{2} 1.0 \mathrm{~g}$ was infused over 15 minutes. Subsequent series of measurements were at the end of $\mathrm{CaCl}_{2}$ infusion and 10 minutes later.

\section{RESULTS}

Mean arterial pressure rose significantly but with no change in heart rate. The increase in rate-pressure-product was not significant (Table II). Cardiac index rose from 1.76 to 1.99 $\mathrm{l} / \mathrm{min} / \mathrm{m}^{2}$, a significant effect which lasted at least 10 minutes after the infusion (Table III). Both stroke volume and work indices were greater at the end of infusion of $\mathrm{CaCl}_{2}$, with stroke work index nearly doubling. Of the central pressures, only mean pulmonary arterial pressure changed significantly, from 17 to 21 to $20 \mathrm{~mm} \mathrm{Hg}$ (Table IV). Neither pulmonary nor systemic resistance changed, but an increase in coronary vascular resistance was statistically significant at the end of infusion (Table V).

Calcium did not change coronary blood flow, oxygen content of the coronary sinus, or $\mathrm{MVO}_{2}$ (Table VI). Likewise, neither arterial nor coronary sinus concentrations of lactate were altered by $\mathrm{CaCl}_{2}$ (Table VII). Mean lactate extraction before calcium was 18 per cent. The myocardium in one patient produced lactate after calcium while the mean for the remainder was 12 and 15 per cent at the two series after calcium. There were no arrhythmias or ST segment changes during the study.

\section{Discussion}

One of us reported in 1973 that, in the first hours after perfusion in which $\mathrm{CaCl}_{2}$ had been added to the prime, total plasma calcium was elevated while the ionized portion remained normal. ${ }^{8}$ Without supplemental calcium, cardiac index may be low early after operation because of subnormal plasma ionized calcium. In our present study cardiac index was low; unfortunately, we did not measure plasma calcium levels. More recently we found ${ }^{9}$ that the chloride was the only calcium salt showing a reproducible 
TABLE II

Changes in Heart Rate, Mean arterial Pressure and RatePressure Product in Response to $\mathrm{CaCl}_{2}$

\begin{tabular}{|c|c|c|c|}
\hline & $\begin{array}{c}\text { Heart Rate } \\
\text { beats/minute }\end{array}$ & $\begin{array}{c}\text { Mean Arterial } \\
\text { pressure } \mathrm{mm} \mathrm{Hg}\end{array}$ & $\begin{array}{c}\text { Rate-Pressure } \\
\text { product }\end{array}$ \\
\hline $\begin{array}{l}\text { Before } \mathrm{CaCl}_{2} \\
\text { At end of infusion } \\
\text { P } \\
10 \text { minutes later } \\
\text { P }\end{array}$ & $\begin{array}{c}78 \pm 14 \\
75 \pm 16 \\
\text { NS } \\
75 \pm 12 \\
\text { NS }\end{array}$ & $\begin{array}{c}77 \pm 6 \\
94 \pm 18 \\
<.01 \\
90 \pm 19 \\
<.01\end{array}$ & $\begin{array}{r}8234 \pm 2128 \\
10109 \pm 3394 \\
\text { NS } \\
9636 \pm 3195 \\
\text { NS }\end{array}$ \\
\hline
\end{tabular}

Mean \pm Standard deviation

NS = Not significant

$P$ values compare findings of the end of the calcium infusion and 10 minutes later, with those before the drug was given.

TABLE III

Changes in Cardiac Indices in Response to $\mathrm{CaCl}_{2}$

\begin{tabular}{cccc}
\hline \hline & $\begin{array}{c}\text { Cardiac index } \\
1 / \mathrm{min} / \mathrm{m}^{2}\end{array}$ & $\begin{array}{c}\text { Stroke volume } \\
\text { index } \\
\mathrm{ml} / \mathrm{beat} / \mathrm{M}^{2}\end{array}$ & $\begin{array}{c}\text { Stroke work } \\
\text { index } \\
\mathrm{Gm} \cdot \mathrm{M} \cdot \mathrm{M}^{2}\end{array}$ \\
\hline $\begin{array}{cccc}\text { Before } \mathrm{CaCl}_{2} \\
\text { At end of infusion }\end{array}$ & $1.76 \pm .38$ & $23.6 \pm 6$ & $21.1 \pm 10$ \\
$\mathrm{P}$ & $1.99 \pm .47$ & $27 \pm 6$ & $40 \pm 13$ \\
10 minutes later & $<.01 \pm .02$ & $<.03$ & $<.02$ \\
$\mathrm{P}$ & $<.02$ & $27 \pm 6$ & $37 \pm 11$ \\
\hline
\end{tabular}

$\mathrm{m} \pm \mathrm{SD}$

$P$ yalues compare subsequent findings to those before calcium.

TABLE IV

Changes in Central Pressures in Response to $\mathrm{CaCl}_{2}$

\begin{tabular}{cccc}
\hline \hline & $\begin{array}{c}\text { RA pressure } \\
\text { mm Hg }\end{array}$ & $\begin{array}{c}\text { Mean } \\
\text { PA pressure } \\
\text { mm Hg }\end{array}$ & $\begin{array}{c}\text { Pulmonary } \\
\text { wedge pressure } \\
\text { mm Hg }\end{array}$ \\
\hline $\begin{array}{cccc}\text { Before } \mathrm{CaCl}_{2} \\
\text { At end of infusion }\end{array}$ & $10 \pm 2$ & $17 \pm 4$ & $11 \pm 2$ \\
P & $10 \pm 2$ & $21 \pm 4$ & $12 \pm 3$ \\
10 minutes later & $\mathrm{NS}$ & $<.04$ & $\mathrm{NS}$ \\
$\mathrm{P}$ & $10 \pm 1$ & $20 \pm 4$ & $12 \pm 2$ \\
\hline
\end{tabular}

$\mathrm{m} \pm \mathrm{SD}$

$\mathrm{RA}=$ right atrium. $\mathrm{PA}=$ pulmonary artery.

$P$ values compare subsequent findings to those before calcium.

highly significant relationship between increases in total calcium and ionic calcium, during whole body perfusion. Chloride is the calcium salt of choice for positive inotropy, is effective and widely used.

How calcium acts on the circulation has been the subject of differing reports. Denlinger's study ${ }^{1}$ was in healthy volunteers at constant depth of halothane anaesthesia. Positive inotropy was clearly seen but heart rate and vascular resistance fell, with no blood pressure change. In patients after CABG, Lappas ${ }^{2}$ found predominantly a blood pressure rise due to a SVR elevation, with no change in cardiac index. Stanley used a different model: the awake calf, before and after insertion of an artificial heart. He found that $10 \mathrm{mg} \cdot \mathrm{kg}^{-1}$ gave the greatest rise in cardiac output and reduction in vascular resistance. ${ }^{10}$ Like other drug studies, the effects of $\mathrm{CaCl}_{2}$ are variously influenced by the model used, the dose and timing of the measurements.

Our study was also in a specific group of 
TABLE V

Changes in Vascular Resistance in Response to $\mathrm{CaCl}_{2}$

\begin{tabular}{cccc}
\hline \hline & $\begin{array}{c}\text { Systemic } \\
\text { vascular } \\
\text { resistance* }\end{array}$ & $\begin{array}{c}\text { Pulmonary } \\
\text { vascular } \\
\text { resistance* }\end{array}$ & $\begin{array}{c}\text { Coronary vascular } \\
\text { resistance } \\
\mathrm{mm} \mathrm{Hg} / \mathrm{ml} / \mathrm{minute}\end{array}$ \\
\hline $\begin{array}{c}\text { Before } \mathrm{CaCl}_{2} \\
\text { At end of infusion } \\
\mathrm{P}\end{array}$ & $\begin{array}{c}1911 \pm 902 \\
2155 \pm 1059\end{array}$ & $505 \pm 297$ & $0.94 \pm .07$ \\
10 minutes later & $\mathbf{N S}$ & $\mathrm{NS}$ & $1.22 \pm .10$ \\
$\mathbf{P}$ & $\mathrm{NS}$ & $525 \pm 431$ & $1.19 \pm .02$ \\
\hline
\end{tabular}

$\mathrm{m} \pm \mathrm{SD} *$ dynes $\cdot \mathrm{sec} \cdot \mathrm{cm}^{-5}$

$\mathrm{P}$ values compare subsequent findings to those before calcium.

TABLE VI

Changes in Coronary Sinus Blood Flow and Oxygen Content and $\mathrm{MVO}_{2}$ IN RESPONSE TO $\mathrm{CaCl}_{2}$.

\begin{tabular}{cccc}
\hline & $\begin{array}{c}\text { CS blood flow } \\
\text { ml/minute }\end{array}$ & $\begin{array}{c}\mathrm{CSO}_{2} \text { content } \\
\mathrm{ml} / \mathrm{l} 00 \mathrm{ml}\end{array}$ & $\begin{array}{c}\text { Myocardial } \mathrm{VO}_{2} \\
\text { ml/minute }\end{array}$ \\
\hline $\begin{array}{c}\text { Before } \mathrm{CaCl}_{2} \\
\text { At end of infusion }\end{array}$ & $88 \pm 34$ & $5.9 \pm 1.3$ & $6.5 \pm 2.2$ \\
$\mathrm{P}$ & $95 \pm 46$ & $5.5 \pm 1.3$ & $7.2 \pm 3.7$ \\
10 minutes later & $\mathrm{NS}$ & $\mathrm{NS}$ & $\mathrm{NS}$ \\
$\mathrm{P}$ & $\mathrm{NS}$ & $5.6 \pm 1.3$ & $6.3 \pm 2.4$ \\
$\mathrm{NS}$ & $\mathrm{NS}$ & $\mathrm{NS}$ \\
\hline
\end{tabular}

$\mathrm{m} \pm \mathrm{SD}$

No differences were seen after calcium, compared to before it.

TABLE VII

Arterial and Coronary Sinus Concentrations of LaCtate IN RESPONSE TO $\mathrm{CaCl}_{2}$

\begin{tabular}{ccc}
\hline \hline & $\begin{array}{c}\text { Art. lactate } \\
\mathrm{mmol} / \mathrm{l}\end{array}$ & $\begin{array}{c}\mathrm{CS} \text { lactate } \\
\mathrm{mmol} / 1\end{array}$ \\
\hline $\begin{array}{c}\text { Before } \mathrm{CaCl}_{2} \\
\text { At end of infusion } \\
\mathrm{P}\end{array}$ & $2.5 \pm 0.8$ & $2.1 \pm 0.8$ \\
10 minutes later & $2.6 \pm 0.9$ & $2.3 \pm 0.8$ \\
$\mathrm{P}$ & $2.5 \pm 0.9$ & $2.1 \pm 0.9$ \\
$\mathrm{NS}$ & $\mathrm{NS}$ & $\mathrm{NS}$ \\
\hline
\end{tabular}

$\mathrm{m} \pm \mathrm{SD}$

patients who needed positive inotropy, not during anaesthesia but three hours after CABG. All had had coronary stenoses but with intact ventricular function before operation. All were revascularized by vein grafts. They were still hypothermic $\left(35^{\circ} \mathrm{C}\right)$ with low cardiac index $\left(1.76 \mathrm{l} / \mathrm{min} / \mathrm{m}^{2}\right)$ and elevated vascular resistance (1911 dynes $\cdot \mathrm{sec} / \mathrm{cm}^{-5}$ ). They had normal right atrial $(10 \mathrm{~mm} \mathrm{Hg})$ and wedge $(11 \mathrm{~mm} \mathrm{Hg})$ pressures. While drowsy, they were responsive, not acidotic and on constant ventilation during the study. One gram of $\mathrm{CaCl}_{2}$ in these patients was a higher dose $\left(14.6 \mathrm{mg} \cdot \mathrm{kg}^{-1}\right)$ than that given in other studies. Hence we gave it over $15 \mathrm{~min}$ utes, although this is much slower than it usually is given in the operating room

In this particular model and setting, $\mathrm{CaCl}_{2}$ improved haemodynamics and enhanced cardiac performance. Cardiac index and blood pressure rose. Unlike Denlinger ${ }^{1}$ and Lappas, ${ }^{2}$ we saw neither a fall nor a rise in vascular resistance, which was gratifying, since it was already elevated, partly due to hypothermia. No blood volume or vasodilating or constricting drugs had been given. With no changes in right atrial and wedge pressures or resistance, the improved cardiac output must have been due to better contractility. As expected, stroke work nearly doubled while stroke volume rose much less.

Mean pulmonary arterial pressure increased from 17 to $21 \mathrm{~mm} \mathrm{Hg}$ and remained so for ten minutes. However pulmonary vascular resistance rose only transiently and not significantly. Lappas, et al. have pointed out the risk of calcium acutely raising PA pressure when it is already over $25 \mathrm{~mm} \mathrm{Hg}$. ${ }^{11}$

The haemodynamic response from this dose of $\mathrm{CaCl}_{2}$ probably was blunted in these patients after two hours of perfusion, 72 minutes of 
cardioplegia and with body temperature still subnormal.

The haemodynamic effects of $\mathrm{CaCl}_{2}$ have been studied before but there has been no information as to whether the increased cardiac work of greater cardiac performance endangers myocardial oxygenation in patients with coronary disease. The special catheter, ${ }^{5}$ which measures total coronary sinus flow and enables arteriovenous sampling across the heart, makes it possible to quantify left ventricular $\mathrm{MVO}_{2}$. Sampling from mid-coronary sinus obtains blood from all segments of left ventricular muscle. Hence changes are global and no information on regional flow and energy metabolism is possible. There is variation in normal coronary blood flow measured from subject to subject, but sequential measurements in the same subject are highly reproducible, as are the responses to drugs. ${ }^{5}$

Mean coronary flow in nine patients after CABG averaged $88 \mathrm{ml} /$ minute, and this was not significantly affected by $\mathrm{CaCl}_{2}$. Mean coronary blood flow for these patients, sedated before anaesthesia, ${ }^{3}$ was $102 \mathrm{ml} /$ minute. Using the same method Ganz found coronary sinus flow to be $128 \mathrm{ml} / \mathrm{min}$ in 35 awake patients with coronary disease. ${ }^{5}$

More important are the indicators of myocardial oxygenation: coronary sinus oxygen content and $\mathrm{MVO}_{2}$. The effect expected from greater cardiac work is greater myocardial oxygen consumption. With no change in arterial content, coronary sinus oxygen content did fall slightly and $\mathrm{MVO}_{2}$ rose from 6.5 to $7.2 \mathrm{ml} /$ minute. While a trend was present, this change was not statistically significant. At least we did not document a large increase in $\mathrm{MVO}_{2}$ from a dose of $\mathrm{CaCl}_{2}$ that had beneficial haemodynamic effects.

Another indicator of oxygenation is lactate. Normally more than 20 per cent of arterial lactate is extracted by the myocardium and used for ATP formation. Less than 10 per cent extraction or more lactate in coronary sinus than in arterial blood indicates anaerobic metabolism and large scale ischaemia. Overall, mean arterial and coronary sinus lactate did not change in the nine patients and lactate continued to be extracted in eight of them. In one patient a change from lactate extraction to production occurred after calcium. This was the oldest patient ( 73 years) in whom there was a greater pressure response (MAP: $77.107-98 \mathrm{~mm} \mathrm{Hg}$ ) than in cardiac output $\left(1.95-2.09-2.231 / \mathrm{min} / \mathrm{m}^{2}\right)$. So in one instance myocardial oxygen supply was exceeded as pressure work greatly increased.

In summary, in the hours immediately after CABG, $15 \mathrm{mg} \cdot \mathrm{kg}^{-1}$ of $\mathrm{CaCl}_{2}$ improved cardiac performance and arterial pressure significantly. Myocardial oxygenation was maintained, although a large rise in arterial pressure compromised it in one patient. We conclude that $\mathrm{CaCl}_{2}$ is a safe and effective drug for treatment of low cardiac output early after CABG.

\section{REFERENCES}

1. Denlinger, J.K., Kaplan, J.A., Lecky, J.H. et al. Cardiovascular responses to calcium administered intravenously to man during halothane anesthesia. Anesthesiology 42: 390-397 (1975).

2. LapPas, D.G., Drop, L.J., Buckley, M.J., et al. Response to calcium chloride during coronary artery surgery (Abstract). Surg. Fonum 26: 234$235(1975)$.

3. Moffitr, E.A., Sethna, D., Gray, R.L., et al. Coronary blood flow, $\mathrm{MVO}_{2}$ and hemodynamics during halothane and morphine anesthesia for coronary artery surgery. Submitted for publication.

4. Swan, H.J., GANz, W., Forrester, J.S., et al. Catheterization of the heart in man in the use of a flow-directed, balloon-tipped catheter. N. Eng. J. Med. 283: 447-450 (1970)

5. GaNz, W., TaMURA, K., Marcus, H.S. et al. Measurement of coronary sinus blood flow by continuous thermodilution in man. Circulation 44: 181-195 (1971).

6. MARBACH, E.P. \& WeIL, M.H. Rapid enzymatic measurements of blood lactate and pyruvate. Clin. Chem. 13: 314-325 (1967).

7. Yang, S.S., Bentivoglto, L.G., MaranhaO V., et al. From Cardiac Catheterization Data To Hemodynamic Parameters. Philadelphia: F.A Davis Co. (1972).

8. Moffitt, E.A., Tarhan, S., Goldsmith, R.S., et al. Pattems of total and ionized calcium and other electrolytes in plasma during and after cardiac surgery. J. Thorac. Cardiovasc. Surg. 65: 751-757 (1973).

9. White, R.D., GoldSMIth, R.S., RODRIGUEZ, R., et al. Plasma ionic calcium levels following injection of chloride, gluconate and gluceptate salts of calcium. J. Thorac. Cardiovasc. Surg 71: 609-613 (1976).

10. Stanley, T.H., ISERn-Amaral, J., Wen-Shin, L., et al. Peripheral vascular versus direct cardiac effects of calcium. Anesthesiology 45: 46-58 (1976).

11. Lappas, D.G, Verlee, T., Schneider, R., et al. Effects of an acute increase in $(\mathrm{Ca}++)$ on pulmonary vasculature (Abstract). Anesthesiology 51: S172 (1979). 


\section{RÉSUMÉ}

Le but de ce travail était de vérifier si les effets circulatoires bénéfiques du chlorure de calcium étaient obtenus au prix d'une augmentation de la consommation myocardique d'oxygène supérieure aux apports. A cette fin, neuf patients venant de subir un pontage aorto-coronarien ont été étudiés trois heures après leur arrivée aux soins intensifs.

Avant l'induction de l'anesthésie, nous leur avions installé sous anesthésie locale une canule dans l'artère radiale et deux cathéters à thermodilution: le premier dans l'artère pulmonaire pour la mesure du débit cardiaque et le second placé sous fluoroscopie dans le sinus coronaire pour la mesure du débit sanguin dans le sinus coronaire (équivalent au débit de l'artère coronaire gauche).

Les mesures suivantes ont été effectuées avant et après l'administration par voic intraveineuse, en quinze minutes, d'un gramme de chlorure de calcium: données hémodynamiques, débit cardiaque et débit du sinus coronaire, contenu en oxygène et en lactate du sang artériel et du sang prélevé dans le sinus coronaire.

L'administration de chlorure de calcium élève le débit cardiaque et la pression artérielle, mais non la résistance vasculaire périphérique. Le débit du sinus coronaire ne s'est pas modifié, ni la consommation d'oxygène myocardique, ni le contenu en oxygène du sinus coronaire. Le taux des lactates dans le sang artériel et dans celui du sinus coronaire ne s'est pas modifié et l'extraction des lactates par le myocarde s'est continuée chez huit des neuf patients. Les effets bénéfiques sur la circulation se sont donc accomplis sans inconvénient pour l'équilibre énergétique du myocarde. 